\title{
REGIONAL BANKS \& FINTECH: A STANDOFF OR PARTNERSHIP?
}

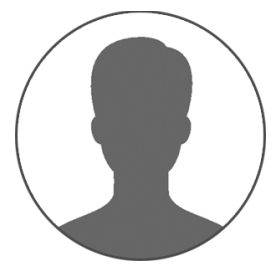

Article history:

Received 16 October 2018

Received in revised form

31 October 2018

Accepted 14 November 2018

Translated 14 March 2019

Available online 29 March 2019

JEL classification: G12

\section{Keywords: regional bank, financial technology, FinTech}

\author{
Tat'yana N.ZVER'KOVA \\ Orenburg State University, Orenburg, Russian Federation \\ tnzverkova@mail.ru \\ https://orcid.org/0000-0002-6540-6154
}

\begin{abstract}
Subject The rise of innovative financial technology and blockchain intensified debates about refocusing the financial market's needs and FinTechs substituting traditional banks. The competition for clients moved to the digital level. Traditional banks are forecasted to step down gradually. Major banks announced changes in their business models to establish the partnership relations with fintech companies and surround themselves with the ecosystem of services. However, Russia has still been waiting for the technological boom. Considering limited financial resources, regional banks need to look for new aspects for cooperating with fintech companies.

Objectives The research analyzed the existing situation in the banking market in terms of the competition of credit institutions with fintech companies. I study what opportunities regional banks have to reshape their business models and set partnership relations with fintech companies.

Methods The research relies upon methods of expert assessment and generalization.

Results Currently, regional banks have no financial resources and technological capabilities to compete with fintech companies. The cooperation strategy may help them survive in the situation.

Conclusions and Relevance Regional banks should not stick to each aspect of FinTech development, but rather focus on the expansion and customization of the customer services, delivery of tailor-made solutions and recommendations through various communication means.
\end{abstract}

The editor-in-charge of this article was Irina M. Vechkanova Authorized translation by Irina M. Vechkanova

The press has been discussing the importance and rile of innovative financial technology in banking for the recent several years. At the end of 2017, explaining a new strategy for 2018-2020, German Gref, the Chairperson of the Management Board of Sberban, stated that he had no vision of contemporary banks in the future. He also added that neither he nor his team would undertake to set up a new bank if they asked to ${ }^{1}$. In his opinion, technological companies, which German

\footnotetext{
${ }^{\dagger}$ For the source article, please refer to: Зверькова Т.Н. Региональные банки и FinTech: противостояние или партнерство // Финансы и кредит. 2018. Т. 24. № 12. С. 2771-2782. URL: https://doi.org/10.24891/fc.24.12.2771

${ }^{1}$ Eremina A. Gref zayavil, chto ne verit v banki [Gref says he does not believe in banks].

URL: https://www.vedomosti.ru/finance/articles/2017/12/14/745310gref (In Russ.)
}

Gref actually considers as competitors, are in fact the beacon for Sberbank.

Does this view prevails in the market? I do some research and evaluate how FinTechs influence the position of regional banks and future development.

V. Solodkii ${ }^{2}$ and A. Krivorotova ${ }^{3}$ justify the opinion stating that the Russian banks mainly transform into technological businesses holding banking licenses or strive to become ones after they endured the digital

\footnotetext{
${ }^{2}$ Solodkii V. Kak IT-industriya ubivaet banki [How does IT sector kill banks?]. URL: https://secretmag.ru/opinions/fintech-kills.htm (In Russ.)

${ }^{3}$ Krivorotova A. Bazel'skii komitet uvidel $v$ fintekhe risk dlya bankov [The Basel Committee considers FinTech as a risk for banks]. URL: https://www.rbc.ru/finances/04/09/2017/59ad67f39a79477e3de93 754 (In Russ.)
} 
revolution. Currently, the world is seeing the largescale race of technologies vying for customers and subsequent intensification of the competition in the digital sector. It is common thinking that FinTech startups put banking businesses at stake.

P. Vigna, M.J. Casey [1], J. Rickards [2], M. Swan [3], S. Chishti, J. Barberis [4] and experts of Pricewaterhouse Coopers $(\mathrm{PwC})^{4}$ believe that the market landscape will change and FinTechs will squeeze traditional banks out of the market within the coming 5 to 10 years.

According to PwC surveys, the overwhelming majority of respondents from the traditional sector of financial services do not have so dramatic expectations, predicting just an insignificant reduction in the scope of banking business, which may be overtaken by FinTech competitors.

According to Ernst \& Young, Russia goes third in the FinTech services market among 20 major markets of the world. Market Penetration index of FinTech services in the Russian largest cities has been constantly growing, reaching 43 percent in 2017 and actually reshaping the existing ecosystem ${ }^{5}$.

Under such circumstances, the Central Bank of Russia could but attempted to create the so called regulatory playground where innovative financial technology and services could be tested in order to forge a mechanism for streamlining the development of innovative financial technology and services, preserving the stability of the financial system and protecting consumer rights.

The above opinions, including the Basel Committee for Banking Supervision ${ }^{6}$, about a vigorous rash of changes, tough competition and danger of FinTechs seem rather apocalyptic for banks and the contemporary financial sector. If such predictions say nothing about major banks in the market, what should we think about medium-sized and smaller regional banks, which are not armored with substantial financial and IT resources.

\footnotetext{
${ }^{4}$ Blurred Lines: How FinTech is Shaping Financial Services. Global FinTech Report. PwC, March 2016.

URL: https://www.pwc.ru/en/banking/publications/fintech-global-reporteng.pdf

${ }^{5}$ FinTech v Rossii i mire: trendy, infrastruktura, uchastniki rynka [FinTech in Russia and worldwide: Trends, infrastructure, market actors]. URL: http://2017.russianinternetforum.ru/news/1288/ (In Russ.)

${ }^{6}$ Krivorotova A. Bazel'skii komitet uvidel v fintekhe risk dlya bankov [The Basel Committee considers FinTech as a risk for banks]. URL: https://www.rbc.ru/finances/04/09/2017/59ad67f39a79477e3de93 754 (In Russ.)
}

However, there are opposite views. As V. Solodkii fairly notes $^{7}$, Russia has not yet experienced the FinTech boom. According to research done by N.I. Morozko [5], S. Pertseva, D. Kopylov [6], A.A. Bakhareva [7], N.I. Kulikov. Yu.V. Kudryavtseva ${ }^{8}$, V.V. Maslennikov, M.A. Fedotova, A.N. Sorokin [8], it would be fair to point out only several breakthough startusp, which virtually work as advertising platforms and search for investors. We still cannot indicate which national financial technology allowed to turn around the consumption of financial services and behavioral patterns of customers.

EY experts believe that traditional banks have big opportunities and stay calm to an extent ${ }^{9}$.

The same tendency is noted by PwC stating that the Russian companies have nothing to worry about so far. According to PwC survey, the Russian respondents have less concerns about the impact that the FinTech sector may possibly have on their businesses. The Russian companies mention new approaches to taking risks and forecasting losses as one of the most important effects financial technology may have. I should also admit that the Russian companies see fewer opportunities of FinTech for the effective use of the existing data and analytics.

In such circumstances, regional banks also take efforts to integrate high technology into services they deliver to customers. However, any successful and significant projects can hardly be seen.

In my opinion, J.F. Sinkey made a good guess of regional banks' failure:

- the inability to satisfy financial needs of the baby boom generation;

- the regulatory burden that causes disparities in the market, which would be more favorable for market actors, other than banks;

- shortage of funds to acquire expensive technology needed to win the competition race;

${ }^{7}$ Solodkii V. Kak IT-industriya ubivaet banki [How does IT sector kill banks?]. URL: https://secretmag.ru/opinions/fintech-kills.htm (In Russ.)

${ }^{8}$ Kulikov N.I., Kudryavtseva Yu.V. [Banks are moving to Internet banking]. Finansy $i$ kredit = Finance and Credit, 2016, no. 29, pp. 2-10. (In Russ.)

${ }^{9}$ Itogovyi dokument Foruma innovatsionnykh finansovykh tekhnologii Finopolis 2016 [White paper of the Forum for Innovative Financial Technology Finopolis 2016].

URL: https://finopolis.ru/program/totalDocumentForumFinnopolis2016. pdf?1524511048 (In Russ.) 
- dissemination of financial innovation (securitization) and development of secondary markets, which would make banking look like a commodity-based business [9].

I should also mention those who advocate the close cooperation and mutual penetration.

According to A. Gots ${ }^{10}$, banks and FinTechs are not competitors in the Russian market since they target at different customers. While banks work with the mass market segment, FinTechs offer a specialty service of high quality at a higher price.

As E. Timko says ${ }^{11}$, there is no competition of banks and FinTechs in Russia and it will not arise. There are several successful FinTech startups which just fit in their niches and unique model, which banks cannot implement due to certain reasons. However, any considerable competition is out of question. There exist a group of startups operating in the b2b segment and offering their products to banks. According to V.D. Milovidov [10-12], S.Yu. Pertseva [13], FinTechs have not yet managed to pushed banks from their market niche.

Nowadays, banks do not have to compete with FinTechs, but rather adopt to rapidly changing market conditions and choose the cooperation path. Possible options range from purchasing FinTechs at a high price to setting up viable technological partnerships.

As a matter of fact, major banks will acquire teams and their technology or have to concede, letting them be nominally free and independent and acting as coinvestors of such projects.

S.Yu. Pertseva [13], A.M. Pogosyan [14], N.E. Dorokhin [15], V.M. Usoskin, V.Yu. Belousova, I.O. Kozyr' [16] spotlight two strategies of banks. First, they acquire operational FinTech projects. Second, they bring u such startups internally. Actually, both scenarios are quite expensive and hardly predictable. They are likely to leave regional banks with small capital out of innovation and technological retrofit of their business.

What remains overlooked is that FinTechs virtually can have significant impact on five aspects, i.e. money transfers and online payment, financial planning, savings and investment, borrowings, and insurance.

\footnotetext{
${ }^{10}$ Gots A. Banki vs fintekh: ugroza, otkuda ne zhdali [Banks vs FinTech: Threats Unexpected]. URL: http://bankir.ru/publikacii/20180122/bankivs-fintekh-ugroza-otkuda-ne-zhdali-10009406/ (In Russ.)

${ }^{11}$ Timko E. Banki dognali startapy [Banks caught up with startups]. URL: https://www.vedomosti.ru/opinion/articles/2017/04/19/686319banki-dognali (In Russ.)
}

However, in reality, the segments are not crucial for regional banks.

Therefore, considering the above conflicting opinions, I point out issues that had a considerable impact on regional banks as part of their partnership relations with FinTechs (Fig. 1).

V.D. Milovidov [12], V.M. Usoskin, V.Yu. Belousova, I.O. Kozyr' [16], T.V. Nikitina, M.A. Nikitin, M.A. Gal'per [17], G.F. Ruchkina [18] predict the survival of few banks. In the best case scenario, there will be about 200 banks in Russia, including 10-20 major State-owned ones united by the common strategy and commitments. The other banks will serve as a kind of in-house credit institution services a specific large enterprise or city, rather than mass retail customers. Large banks will pick up the pace of buying successful FinTech projects, expanding their portfolio of products and services. Later on they will be developing innovative laboratories.

Most specialists hold that it is almost a reality but still in the future. Currently, regional banks have some time due to financial difficulties, small financial market in Russia, drop in the purchasing power and toughening governmental control. According to T.V. Nikitina, M.A. Nikitin, M.A. Gal'per [17], G.F. Ruchkina [18], in Russia, some services have not been properly developed yet, demonstrating the low demand. In Russia, b2b websites are usually used by macrofinance institutions offering loans at much higher rates than banks. The mobile acquiring market is very narrow.

In my opinion, in such circumstances, as FinTechs grow stronger as competitors, regional banks should consider their limited financial resources and adjust their business models so as to organize the partnership relations with FinTechs and create the surrounding ecosystem of services, follow strategies proposed by J.F. Sinkey [9] and suggestions of PwC and EY'12. In the context of regional banks, they provide the following recommendations.

1. Investing in niches. Being hardly comparable with State-owned banks, regional banks should stream their funds and resources to practices where they

\footnotetext{
${ }^{12}$ Blurred Lines: How FinTech is Shaping Financial Services. Global FinTech Report. PwC, March 2016.

URL: https://www.pwc.ru/en/banking/publications/fintech-global-reporteng.pdf

EY FinTech Adoption Index - Russia. Key Trends. 2016. URL: https://www.ey.com/Publication/vwLUAssets/EY-fintechindex-russia-eng/\$FILE/EY-fintech-index-russia-eng.pdf
} 
are likely to have a competitive advantage. Such niches usually include VIP banking services for the wealthiest people of the region, data processing.

2. Sourcing out functions as much as possible. Regional banks may contract out big data processing. Any risks of data processing on an outsourcing basis may be offset if the data are divided among several providers of cutting-edge blockchain technology.

3. Positioning the small size as an advantage. Admittedly, some brand new technologies flourish most of all in small regional banks, with their size becoming their strength. Smaller banks may outperform larger ones by identifying real needs of their customers, rather than the generic and robotic servicing style. It is vexing to hear welcoming greetings of automated voice response, never ending ads and menu options.

4. Applying for services of online application providers. Such providers open access to brand new Internet technologies and services to regional banks at a certain price. Actively adopting e-commerce technologies, online applications of banks help estimate loans, provide loans to small entities, handle mortgage transactions, etc.

5. Developing the inner capability for integration. Regional banks have to deal with diverse systems and partners. Banks need their own high professional IT-teams, which would integrate systems and processes, especially databases, networks and web applications.

6. Avoiding the extreme thriftiness in key aspects. If the bank's management clearly understands that new technology allows to identify competitors, they should not tighten the purse strings for the talent who would be capable of activating the innovation. Historically, the personnel, who have no appropriate skills and are unsatisfied with the management, may ruin strengths of the best ever technological innovation. Furthermore, undervalued specialists may leave for competitors and offer their skills there.

7. Revisiting decisions. It is necessary to think FinTech. New formats of cooperation, such as partnership and joint venture, should be tested. For that, priority and promising lines should be determined, defining incentives for attractive professionals who have sufficient business skills.
8. Partnership as the single method for banks to cooperate with FinTechs. Partnership-based cooperation constitutes a simple and flexible way to establish the relationship with a technological company and effectively use its capabilities in the safe environment for testing. Traditional market actors will strengthen their competitiveness, implement their decisions and launch their products to the market within a shorter period of time through the partnership with FinTechs. If FinTechs act as providers of services, their ideas and processes can be adopted and borrowed.

9. Creating an agile business. FinTechs work rapidly, correct their mistakes quickly and take risks without hesitation. Banks should consider whether the dynamism fits their business processes and to what extent it meets shareholders' expectations.

10. Creating the conditions. Banks should reinforce the positions through active involvement into the sector processes and launch venture projects, business incubators and programs for acceleration.

11. Encouraging and Supporting Innovation. Banks should master the development of innovation and attract high-profile talent who combine relevant technological knowledge and sales skills. Thus, they should revise their manner of management, decline the traditional top-to-bottom approach and adopt the innovation-oriented model.

12. Building the positive brand for employment. Banks should liaison with startups and build corporate brands with the technologically-oriented philosophy.

13. Reshaping the HR development system. To prepare the training programs for mastering new programming knowledge or other skills relating to digital technologies, it is necessary to create opportunities for employees to unite into networks locally so that they could sort out new trends and learn new technology;

14. Digitizing the work space. To hire the young talent, banks should interact with their employees in another way. They should revise professional promotion mechanisms, implement a set of incentives or contract out some workload to freelancers.

The proposed guidelines will unavoidably make banks ensure the protection of their niches using new technology and providers. 
Under the current circumstanced, regional banks can but speed up. As PwC predicts, the speed, security and digitization will become cornerstones of the payment ecosystem.

Regional banks are now in a kind of trap seeing that their market share are taken over not only by State-owned banks but also FinTechs. What may mainly result from the FinTech segment development is the huge number of new business models in the sector of financial services. According to PwC, the new business model standard requires to decline the linear strategy for product promotion and opt for the customeroriented model. As part of the new model, providers of financial services act as intermediaries, thus allowing customer to get advice and interact with all parties of the process via various channels. Hence FinTechs intensify the focus on customers and prioritize it in the context of their business model.

In my opinion, it would be sensible to look back at ideas of Hans-Ulrih Doerig calling to provide customers not reasonable and sound recommendations, rather than banking products, so that they could make decisions on all financial issues they have [19]. It is obvious that banks actually fail to render so consistent, independent, unbiased and quality advisory services, which customer expect to get. Regional banks should necessarily strive to improve and customize customer services. 


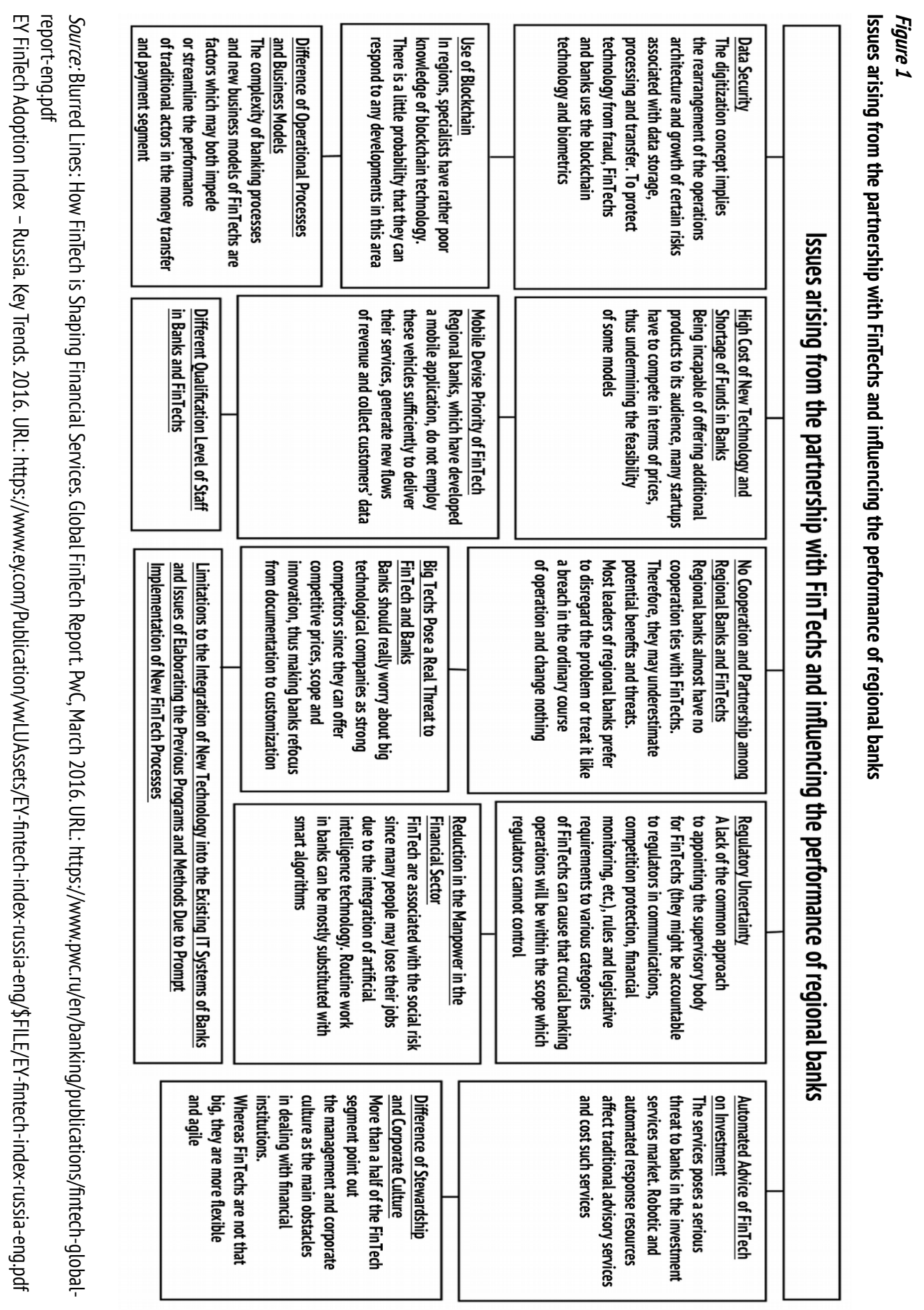

Please cite this article as: Zver'kova T.N. Regional Banks \& Fintech: A Standoff or Partnership. Digest Finance, 2019, vol. 24, iss. 1, 


\section{References}

1. Vigna P., Casey M.J. Epokha kriptovalyut. Kak bitkoin i blokchein menyayut mirovoi ekonomicheskii poryadok [The Age of Cryptocurrency: How Bitcoin and the Blockchain Are Challenging the Global Economic Order]. Moscow, Mann, Ivanov i Ferber Publ., 2018, 432 p.

2. Rickards J. Zolotoi zapas. Pochemu zoloto, a ne bitkoiny - valyuta XXI veka? [The New Case for Gold]. Moscow, Eksmo Publ., 2017, 192 p.

3. Swan M. Blokchein. Skhema novoi ekonomiki [Blockchain: Blueprint for a New Economy]. Moscow, Olimp-Biznes Publ., 2017, 240 p.

4. Chishti S., Barberis J. Fintekh: Putevoditel' po noveishim finansovym tekhnologiyam [The FINTECH Book: The Financial Technology Handbook for Investors, Entrepreneurs and Visionaries]. Moscow, Al'pina Pablisher Publ., 2017, 676 p.

5. Morozko N.I., Didenko V.Yu. Osnovnye trendy razvitiya industrii finansovykh tekhnologii: monografiya [The main trends in the development of the financial technology industry: a monograph]. Moscow, Rusains Publ., 2017, 176 p.

6. Pertseva S.Yu., Kopylov D.A. [The Basics of Fintech Industry and Implementation of Its Principles in the Case of Payments and Transfers Segment]. Problemy natsional'noi strategii = Problems of National Strategy, 2018, no. 4, pp. 186-195. URL: https://riss.ru/images/pdf/journal/2018/4/13.pdf (In Russ.)

7. Bakhareva A.A. [Prospects for the development of the banking sector in the context of the introduction of modern financial technologies]. Simvol nauki, 2017, vol. 1, no. 1, pp. 12-14.

URL: https://cyberleninka.ru/article/n/perspektivy-razvitiya-bankovskogo-sektora-v-usloviyah-vnedreniyasovremennyh-finansovyh-tehnologiy (In Russ.)

8. Maslennikov V.V., Fedotova M.A., Sorokin A.N. [New financial technologies change our world]. Vestnik Finansovogo universiteta = Finance: Theory and Practice, 2017, vol. 21, no. 2, pp. 6-11.

URL: https://cyberleninka.ru/article/n/novye-finansovye-tehnologii-menyayut-nash-mir (In Russ.)

9. Sinkey J.F. Finansovyi menedzhment $v$ kommercheskom banke i v industrii finansovykh uslug [Commercial Bank Financial Management in the Financial Services Industry]. Moscow, Al'pina Pablisher Publ., 2017, 1018 p.

10. Milovidov V.D. [Big Data in the capital market: is there an advent of a new age of financial services?]. Strakhovoe delo = Insurance Business, 2016, no. 10, pp. 11-20. (In Russ.)

11. Milovidov V.D. [Information Asymmetry and Big Data: Should Financial Market Paradigm Be Revised?]. Mirovaya ekonomika i mezhdunarodnye otnosheniya = World Economy and International Relations, 2017, vol. 61, no. 3, pp. 5-14. (In Russ.) URL: https://doi.org/10.20542/0131-2227-2017-61-3-5-14

12. Milovidov V.D. Filosofiya finansovogo rynka [Philosophy of the financial market]. Moscow, Magistr Publ., 2013, $272 \mathrm{p}$.

13. Pertseva S.Yu. [FINTECH: Mechanism of Function]. Innovatsii v menedzhmente = Innovations in Management, 2017, no. 12, pp. 50-53. URL: https://mgimo.ru/upload/iblock/398/elibrary_29908887_16672494.pdf (In Russ.)

14. Pogosyan A.M. [Innovative payment instruments in the digital economy]. Nauchnye zapiski molodykh issledovatelei = Scientific Notes of Young Scientists, 2017, no. 3, pp. 63-67. URL: https://cyberleninka.ru/article/n/innovatsionnye-platezhnye-instrumenty-v-tsifrovoy-ekonomike (In Russ.)

15. Dorokhin N.E. [Forming an institutional model for alternative financing]. Ekonomika: vchera, segodnya, zavtra= Economics: Yesterday, Today and Tomorrow, 2018, vol. 8, no. 2A, pp. 139-146.

URL: http://www.publishing-vak.ru/file/archive-economy-2018-2/15-dorokhin.pdf (In Russ.)

16. Usoskin V.M., Belousova V.Yu., Kozyr' I.O. [Financial Intermediation in a New Technology Environment]. Den'gi $i$ kredit = Russian Journal of Money and Finance, 2017, no. 5, pp. 14-21. (In Russ.)

Please cite this article as: Zver'kova T.N. Regional Banks \& Fintech: A Standoff or Partnership. Digest Finance, 2019, vol. 24, iss. 1, pp. 13-20. https://doi.org/10.24891/df.24.1.13 
17. Nikitina T.V., Nikitin M.A., Gal'per M.A. [The role of FINTECH segment companies and its place on the financial market of Russia]. Izvestiya sankt-peterburgskogo gosudarstvennogo ekonomicheskogo universiteta = Bulletin of Saint Petersburg State University of Economics, 2017, no. 1-2, pp. 45-48.

URL: https://cyberleninka.ru/article/n/rol-kompaniy-segmenta-finteh-i-ih-mesto-na-finansovom-rynke-rossii (In Russ.)

18. Ruchkina G.F. [Banking activity: transfer to new operation model or FINTECH as new reality]. Bankovskoe pravo = Banking Law, 2017, no. 4, pp. 55-62. (In Russ.)

19. Doerig Hans-Ulrih. Universal'nyi bank - bank budushchego. Finansovaya strategiya na rubezhe veka [Universal Bank - The Bank of the Future. Financial Strategy at the Turn of the Century]. Moscow, Mezhdunarodnye otnosheniya Publ., 1999, 384 p.

\section{Conflict-of-interest notification}

I, the author of this article, bindingly and explicitly declare of the partial and total lack of actual or potential conflict of interest with any other third party whatsoever, which may arise as a result of the publication of this article. This statement relates to the study, data collection and interpretation, writing and preparation of the article, and the decision to submit the manuscript for publication. 